\title{
Klub Demokratycznej Profesury w Poznaniu w latach (1949) - 1950-1953
}

Zamiary całkowitego podporządkowania szkolnictwa wyższego w Polsce przez władze komunistyczne były widoczne niemal od chwili rozpoczęcia odbudowy uniwersytetów i szkół wyższych ze zniszczeń wojennych w 1945 r. Nowa władza nie mogła sobie pozwolić na pozostawienie środowiska akademickiego poza kontrolą. Celem było organizacyjne i ideologiczne podporządkowanie uniwersytetów oraz kręgów naukowych. Uniwersytety miały być przekształcone w kuźnie wysoko kwalifikowanych kadr inteligencji ideowo związanych z nowym ustrojem.

Komuniści dążyli do podporządkowania sobie szkół wyższych i kadry naukowej nie tylko poprzez zarządzenia administracyjne, ale także poprzez działalność różnego rodzaju towarzystw, organizacji i stowarzyszeń, które miały za zadanie gromadzić wykładowców oraz badaczy i kształtować ich w duchu socjalistycznym. Za pomocą tych towarzystw i organizacji (o określonych celach politycznych i formie działania) planowano uzyskać w środowisku akademickim przychylność i poparcie dla zmian, które zachodziły w kraju. Jedną z takich organizacji był Klub Demokratycznej Profesury (KDP), którego oddziały powstały we wszystkich ośrodkach akademickich w Polsce ${ }^{1}$.

Instancją nadrzędną, finansującą Kluby i kierującą ich działalnością był Centralny Komitet Koordynacyjny Demokratycznej Profesury z siedzibą w Warszawie.

${ }^{1}$ B. Krawiec, Zaangażowanie polityczne profesorów wyższych szkót specjalistycznych Wroctawia w latach 1945-1999, [w:] Studia z dziejów oświaty i myśli pedagogicznej XVIII-XX wieku, pod red. A. Haratyk i M. Piwowarczyka, Wrocław 1997, s. 118. 


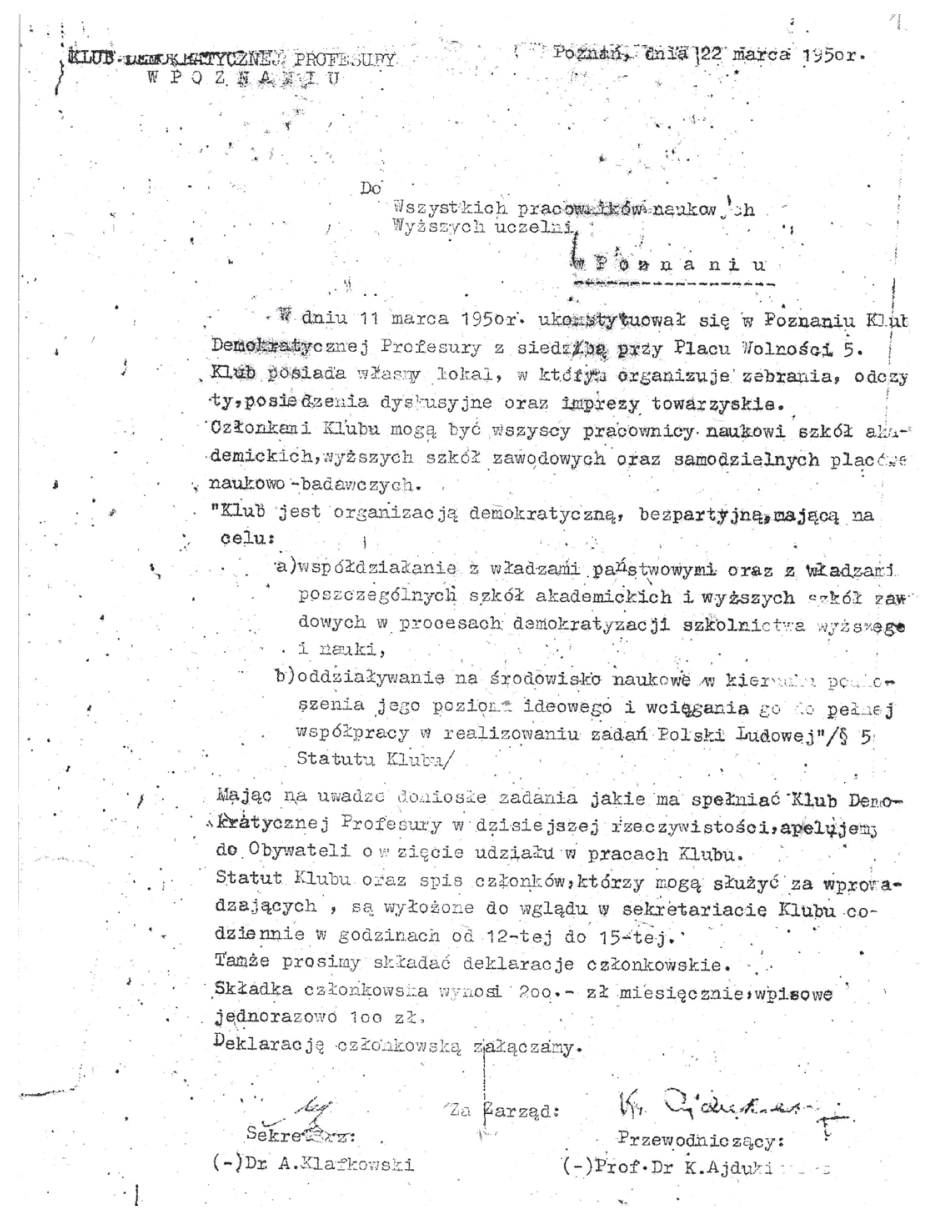

Ulotka informacyjna o ukonstytuowaniu się

Klubu Demokratycznej Profesury w Poznaniu

KDP-y, wbrew swej nazwie, skupiały nie tylko profesorów. Mógł do nich należeć każdy pracownik naukowy wyższej uczelni w danym mieście. Utworzone w Warszawie, Krakowie, Łodzi, Wrocławiu i innych miastach uniwersyteckich Kluby nosiły różne nazwy². Członkowie stowarzyszenia publikowali m.in. na łamach „Myśli Współczesnej” - miesięcznika naukowego

2 Tamże, s .118-119, przypis 5. Więcej na temat Klubów Demokratycznej Profesury i ich funkcjonowania zob. m.in.: K. Wyka, Cele i zadania Klubów Profesury Demokratycznej, „Życie Nauki" 1950, nr 1-2, s. 35-45; W. Rolbiecki, Przemiany społecznego ruchu naukowego w Polsce Ludowej, [w:] Życie naukowe w Polsce w drugiej połowie XIX i w XX wieku. Organizacje i instytucje, pod red. B. Jaczewskiego, Wrocław 1987, s. 373; tegoż, Geneza Polskiej Akademii Nauk (1930-1952), Wrocław 1990. 
poświęconego filozofii i problemom społecznym, wydawanego w Łodzi w latach 1946-1951².

Pierwszy Klub Demokratycznej Profesury powstał w Łodzi z pomysłu Adama Schaffa. Oficjalnie - z inicjatywy własnej środowiska akademickiego, realnie - jak ustalił Jan Nosko (1985) - poprzez skryte działania Wydziału Propagandy i Agitacji Komitetu Łódzkiego Polskiej Partii Robotniczej. Pierwsza narada w sprawie „bezpartyjnego” klubu odbyła się w Wydziale już 1 lutego 1945 r. W efekcie w mieszkaniu prof. Jerzego Jakubowskiego, medyka, uruchomiono towarzyskie spotkania pod przewodnictwem przyszłego rektora Uniwersytetu Łódzkiego Tadeusza Kotarbińskiego ${ }^{4}$.

Poznański Klub Demokratycznej Profesury ${ }^{5}$ został powołany 17 grudnia 1949 r. Na zebraniu grupy organizacyjnej wyłoniono Tymczasowy Zarząd, na czele którego stanął rektor Uniwersytetu Poznańskiego prof. Kazimierz Ajdukiewicz ${ }^{6}$; sekretarzem został ówczesny dr Alfons Klafkowski ${ }^{7}$. Zadaniem Klubu jako instancji bezpartyjnej była współpraca z władzami państwowymi w procesie demokratyzacji szkolnictwa wyższego oraz oddziaływania na środowisko naukowe w celu podnoszenia jego poziomu ideologicznego. Zadania te Klub miał realizować przez organizowanie życia towarzyskiego swoich członków.

Przez kilka pierwszych miesięcy prace przy organizacji Klubu nie postępowały naprzód. Działalność swą rozpoczął dopiero wiosną następnego roku. Zarząd ukonstytuował się 11 marca 1950 r., a 22 marca wydał odezwę, w której czytamy m. in., że członkami stowarzyszenia mogą być wszyscy pracownicy naukowi szkół akademickich, wyższych szkół zawodowych oraz samodzielnych placówek naukowo-badawczych. Klub miał być organizacją demokratyczną, bezpartyjną, mającą na celu:

${ }^{3}$ Pierwszym redaktorem naczelnym pisma był prof. Józef Chałasiński (1904-1979) - socjolog, profesor i rektor Uniwersytetu Łódzkiego (także członek Klubu Demokratycznej Profesury), a od numeru 10. z 1948 r. - Adam Schaff (1913-2006), filozof. Ukazało się 67 numerów czasopisma. W 1951 r. jego miejsce zajął kwartalnik „Myśl Filozoficzna”.

${ }^{4}$ P. Hibner, Samotność klerków. Kartki $z$ dziejów nauki w Polsce, forumakad.pl/archiwum/ 2001/10/artykuly/20-kartki_z_dziejow_nauki_w_polsce.htm., dostęp z dnia 18 stycznia 2015 r.

${ }^{5} \mathrm{~W}$ poznańskim środowisku akademickim, wśród jego krytyków, Klub Demokratycznej Profesury funkcjonował pod prześmiewczą nazwą „KaDuPa”.

${ }^{6}$ Kazimierz Ajdukiewicz (1890-1963) - filozof i logik, reprezentant szkoły lwowsko-warszawskiej, profesor Uniwersytetu Jana Kazimierza, Uniwersytetu Poznańskiego (w latach 1948-1952 - jego rektor) i Uniwersytetu Warszawskiego. Członek PAU i PAN.

7 Alfons Klafkowski (1912-1992) - prawnik. Od 1945 r. pracownik naukowo-dydaktyczny Uniwersytetu im. Adama Mickiewicza w Poznaniu. Był m.in. kierownikiem Katedry Prawa Międzynarodowego Publicznego (1950-1968), prodziekanem (1950-1952) i dziekanem (1952-1955) Wydziału Prawa, rektorem (1956-1962), kierownikiem Instytutu Nauk Prawno-Ustrojowych (1968-1978), prezesem Trybunału Konstytucyjnego (1985-1989) i członkiem Rady Krajowej PRON (1983). 


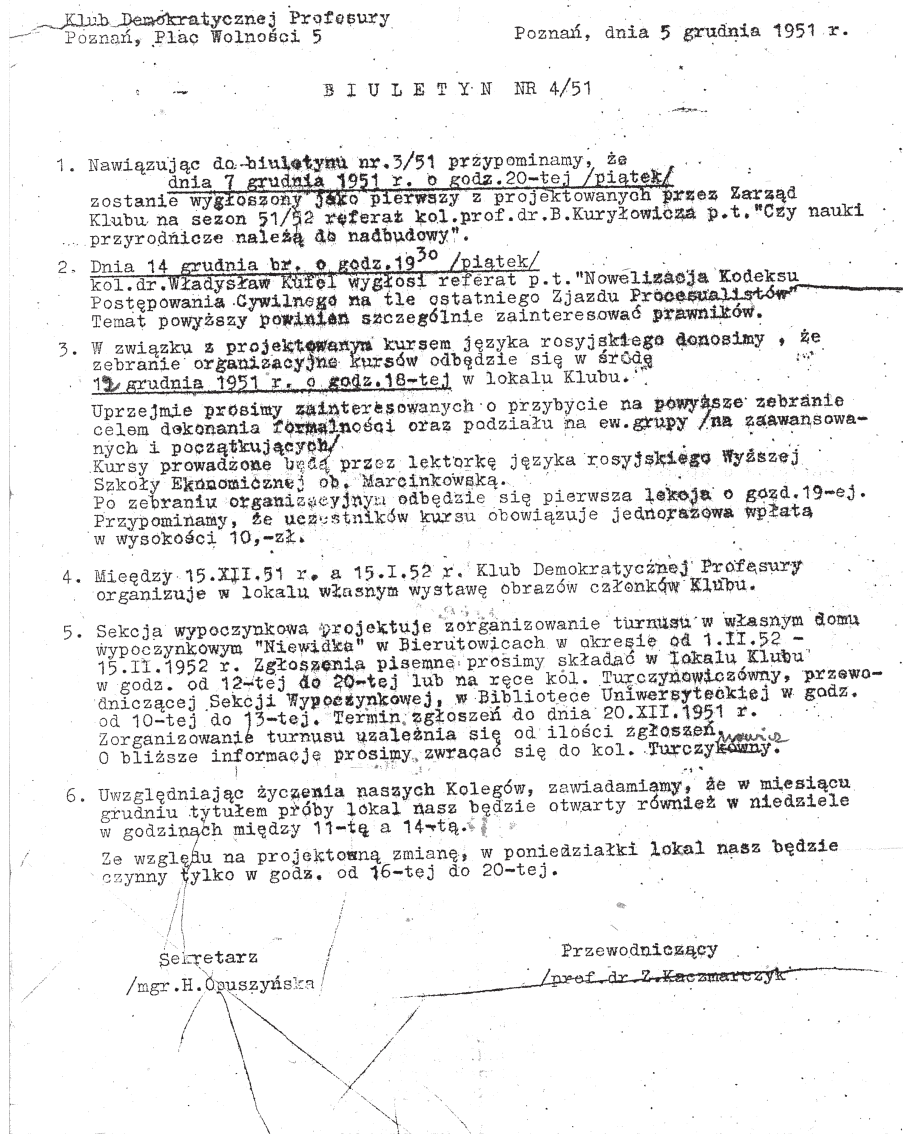

Biuletyn nr 4/51 wydawany przez Klub Demokratycznej Profesury w Poznaniu

a) współdziałanie z władzami państwowymi oraz z władzami poszczególnych szkół akademickich i wyższych szkół zawodowych w procesach demokratyzacji szkolnictwa wyższego i nauki,

b) oddziaływanie na środowisko naukowe w kierunku podnoszenia jego poziomu ideowego i wciągania go do pełnej współpracy w realizowaniu zadań Polski Ludowej (par. 5. statutu Klubu) ${ }^{8}$.

${ }^{8}$ Polska Akademia Nauk Archiwum w Warszawie Oddział w Poznaniu (dalej PANAWOP), Materiały Stefana Błachowskiego, j.a. 118, Odezwa Zarządu Klubu Demokratycznej Profesury w Poznaniu z 22 marca 1950 r. do wszystkich pracowników naukowych wyższych uczelni, k. 1; Archiwum Państwowe w Poznaniu (dalej APP), zespół Komitet Wojewódzki Polskiej Zjednoczonej Partii Robotniczej w Poznaniu (dalej KW PZPR), Statut Stowarzyszenia Klub Demokratycznej Profesury w Poznaniu, k. 56-59. 
Tego samego dnia skierowano pismo o rejestrację stowarzyszenia, adresowane do Zarządu Miejskiego Poznania Wydziału Społeczno-Politycznego, które podpisało szesnaście osób ${ }^{9}$.

Oczywiście, działalność Klubu jako organizacji demokratycznej w ówczesnych realiach politycznych była czystą fikcją. Klub miał przede wszystkim realizować par. 5. statutu poprzez wykłady z dorobku naukowego ZSRR i metodologii marksistowsko-leninowskiej, odczyty, zebrania i posiedzenia dyskusyjne oraz organizowanie życia towarzyskiego członków stowarzyszenia ${ }^{10}$.

1 kwietnia 1950 r. odbyło się Walne Zgromadzenie Klubu, podczas którego wybrano nowy Zarząd. Ten na pierwszym posiedzeniu 12 kwietnia dokonał wyboru przewodniczącego, którym został prof. dr Stefan Błachowski ${ }^{11}$.

Siedziba Klubu przez cały okres jego funkcjonowania w Poznaniu mieściła się przy pl. Wolności 5.

W maju i czerwcu 1950 r. w siedzibie stowarzyszenia odbyło się pięć zebrań, w czasie których wysłuchano i omówiono referaty następujących autorów: 11 maja - Stanisław Teisseyre, Drogi rozwojowe malarstwa wspótczesnego; 16 maja - dr Zbigniew Janowicz, Nowy ustrój administracyjny w Polsce (wprowadzenie terenowych organów jednolitej władzy państwowej; 23 maja - doc. dr Antoni Horst, Energia atomowa stwarza nowe problemy w medycynie; 30 maja - prof. dr Zdzisław Kaczmarczyk i doc. dr Michał Sczaniecki, Nowy podział historii; 6 czerwca - prof. dr Marian Zimmermann, Przebudowa polskiego prawa administracyjnego w systemie gospodarki planowej; 13 czerwca - dr Julian Hubert, Marksizm-leninizm w systemie nauczania Uniwersytetów i wyższych zakładów naukowych $w$ Z.R.R.R ${ }^{12}$.

${ }^{9}$ W kolejności podpisów: prof. Kazimierz Ajdukiewicz, prof. Bolesław Kuryłowicz - członek PZPR, prof. Stefan Poradowski, prof. Zygmunt Pietruszczyński, prof. Józef Jan Bosowski, prof. Jerzy Suszko, prof. Marian Zimmermann, prof. Józef Janicki, prof. Adam Wiegner, mgr Wiktor Jaśkiewicz - członek PZPR, dr Alfons Klafkowski, dr Bohdan Kiełczewski, dr Antoni Linke, mgr Maciej Wiewiórkowski, mgr Szczęsny Gnatowski, mgr Czesław Madajczyk - członek PZPR. APP, zespół KW PZPR, sygn. 3325. Kopia pisma do Zarządu Miejskiego w Poznaniu Wydział Społeczno-Polityczny, brak paginacji.

10 T. Kuta w swoich wspomnieniach ujął to następująco: „Chodziło głównie o to, aby przedwojennej kadry naukowej nie odsuwać na bok życia społecznego i traktować jej przez to jako wrogą ustrojowi" (T. Kuta, Wspomnienia jako studenta i pracownika, [w:] Studia i materiaty z dziejów Uniwersytetu Wrocławskiego, t. 2, Wrocław 1993, s. 257); Zob. też E. Mania, Znaczenie POP PZPR w procesie sowietyzacji uczelni (1948-1956). Przypadek Uniwersytetu Poznańskiego, [w:] Letnia szkoła historii najnowszej 2011, pod red. P. Gasztolda-Senia i Ł. Kamińskiego, Warszawa 2012, k. 26.

11 AAP, zespół KW PZPR, sygn. 3325, Ocena pracy Klubu Demokratycznej Profesury w Poznaniu, k. 60. Stefan Błachowski (1889-1962), psycholog, profesor Uniwersytetu Poznańskiego, w latach 1946-1948 rektor Uniwersytetu Poznańskiego.

12 PANAWOP, Materiały Stefana Błachowskiego, j. 118, pismo okólne Zarządu do członków Klubu, k. 3. 


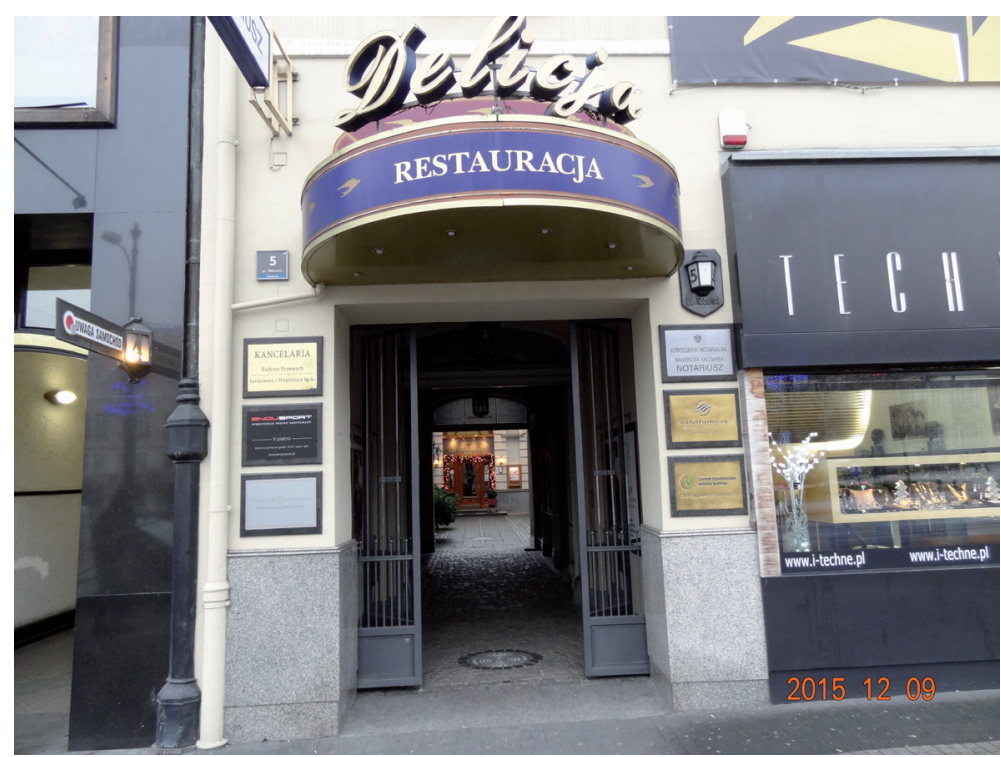

Widok na bramę wejściową do budynku przy pl. Wolności 5 w Poznaniu, gdzie mieścił się Klub Demokratycznej Profesury (fot. J. Matysiak)

W pierwszym roku działalności, obok prac czysto organizacyjnych (remont lokalu, wyposażenie w meble klubowe i bufet), Zarząd położył nacisk na zorganizowanie zebrań dyskusyjnych w oparciu o referaty wygłoszone przez członków Klubu oraz zaproszonych gości. Poziom wystąpień był różny; od gloryfikujących osiągnięcia nauki, gospodarki oraz kultury ZSRR po referaty z różnych dziedzin nauki bez akcentów politycznych. Największą frekwencję miały zebrania, podczas których zaproszeni goście, mianowicie podsekretarz stanu w Ministerstwie Finansów Leon Kurowski oraz podsekretarz stanu w Ministerstwie Szkolnictwa Wyższego Włodzimierz Michajłow, omówili znaczenie i perspektywy I Kongresu Nauki Polskiej ${ }^{13}$. Łącznie w okresie sprawowania funkcji przewodniczącego Klubu przez prof. Błachowskiego przedstawiono dwanaście referatów dotyczących różnych zagadnień naukowych i społeczno-politycznych. Zarząd zebrał się w ciągu roku sprawozdawczego jedenaście razy, w tym na siedmiu protokołowanych posiedzeniach i na czterech nieprotokołowanych zebraniach, zwołanych dorywczo dla omówienia i załatwienia drobniejszych spraw ${ }^{14}$.

Mimo starań nie udało się natomiast Zarządowi zrealizować kursów szkolenia ideologicznego dla wszystkich pracowników naukowych po-

13 Autorowi nie udało się ustalić, kiedy podsekretarze stanu wygłosili ten referat.

14 PANAWOP, Materiały Stefana Błachowskiego, Sprawozdanie Przewodniczącego Klubu Demokratycznej Profesury w Poznaniu za czas od 1 kwietnia 1950 do 24 kwietnia 1951 złożone na Walnym Zebraniu Klubu w dniu 24 IV 1951 r., k. 11. 
znańskich szkół wyższych. W kwietniu 1951 r. Klub liczył przeszło trzystu członków, wśród których można wymienić tak znanych przedstawicieli poznańskiej nauki, jak: Janusz Deresiewicz - prawnik; Antoni Horst - fizjolog i genetyk; Witold Hensel - archeolog, mediewista; Zbigniew Janowicz - prawnik; Zdzisław Kaczmarczyk - historyk państwa i prawa; Alfons Klafkowski prawnik; Kazimierz Miętkiewski - histolog; Michał Sczaniecki - historyk państwa i prawa, oraz Stanisław Waszak - statystyk i demograf.

W podsumowaniu sprawozdania za pierwszy rok działalności Klubu, które przedstawił na Walnym Zebraniu w kwietniu $1951 \mathrm{r}$. przewodniczący prof. Stefan Błachowski, czytamy m.in. „Na zakończenie mego sprawozdania pozwalam sobie zwrócić uwagę na to, że ubiegły rok sprawozdawczy był właściwie pierwszym rokiem funkcjonowania Klubu, okresem poszukiwania i tworzenia form dla działalności Klubu. Obecnie, kiedy uporządkowane zostały liczne i nie zawsze łatwe sprawy administracyjne, kiedy Klub ustalił się w wyraźnych formach organizacyjnych i gdy liczba członków wzrosła do pokaźnej liczby 325, wyrażam nadzieję, że nowemu Zarządowi, który na dzisiejszym Walnym Zebraniu zostanie wybrany, uda się rozwinąć działalność Klubu na szerszą, niż dotychczas, skalę ku zadowoleniu i pożytkowi wszystkich jego członków"15.

Wydawać by się mogło, że jak na pierwszy rok istnienia nowo powstałego towarzystwa, ze względu na liczbę wygłoszonych referatów oraz na liczbę członków, działalność Klubu można by uznać za satysfakcjonującą.

Odmienne zdanie w tej kwestii miał Wydział Oświaty Komitetu Wojewódzkiego Polskiej Zjednoczonej Partii Robotniczej w Poznaniu. W Ocenie pracy Klubu Demokratycznej Profesury w Poznaniu z maja 1951 r. Komitet Wojewódzki zarzucał Zarządowi realizowanie w sposób niedostateczny zadań stojących przed Klubem. Zdaniem autora Oceny przyczyny tego stanu rzeczy były dwie: zły styl pracy Zarządu Klubu oraz brak opieki i kontroli tak ze strony Centralnego Komitetu Koordynacyjnego, jak i - przede wszystkim ze strony egzekutyw POP przy wyższych uczelniach ${ }^{16}$.

„Zebrania Klubu odbywały się przeważnie przy obecności połowy lub mniej członków. Zarząd nie miał opracowanego długofalowego planu pracy, działał od wypadku do wypadku. Program działalności Klubu nie był realizowany. Bezplanowy i często doraźny dobór tematyki referatowej na posiedzeniach wpływał ujemnie na frekwencję członków. Przy ogólnej liczbie

15 PANAWOP, Materiały Stefana Błachowskiego, Sprawozdanie Przewodniczącego Klubu Demokratycznej Profesury w Poznaniu za czas od 1 kwietnia 1950 do 24 kwietnia 1951 złożone na Walnym Zebraniu Klubu w dniu 24 IV 1951 r., k. 11.

16 APP, KW PZPR w Poznaniu, sygn. 3325, Ocenia pracy Klubu Demokratycznej Profesury w Poznaniu, k. 60. 


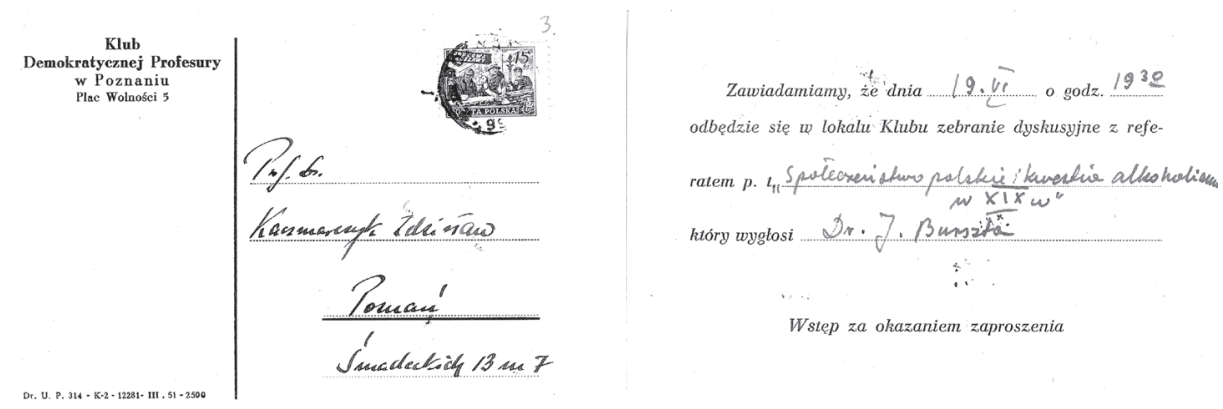

Zawiadomienie adresowane do prof. Zdzisława Kaczmarczyka o zebraniu dyskusyjnym w lokalu Klubu z referatem dr. J. Burszty Społeczeństwo polskie $i$ kwestia alkoholizmu $w X I X w$.

317 członków na zebraniach w końcu roku 1950 obecnych było 30-40 członków." - czytamy w Ocenie ${ }^{17}$.

Nie bez winy był tutaj czynnik nadzorczy, czyli Centralny Organ Koordynacyjny, który przez cały pierwszy rok nie przekazał poznańskiemu Klubowi żadnych wytycznych i nie odpowiadał na przesłany przez Klub program działalności i sprawozdania.

Autor sprawozdania zwrócił uwagę na słabą opiekę ze strony egzekutyw POP przy wyższych uczelniach w Poznaniu, z wyjątkiem POP przy Uniwersytecie Poznańskim, która „w początkowym okresie działalności Klubu, od czasu do czasu zainteresowała się działalnością tego [stowarzyszenia]. Od początku roku akademickiego 1950/51 i [również - J.M.] POP przy UP zaprzestała interesowania się pracą Klubu"18.

Wydaje się, że krytyczna ocena działalności Klubu (a zatem i Zarządu) miała związek z osobą przewodniczącego. Możemy domniemywać, że Stefan Błachowski, przedwojenny profesor uniwersytecki, mógł nie spełniać oczekiwań członków Komitetu Wojewódzkiego PZPR w Poznaniu ${ }^{19}$ wobec zdań, jakie wynikały z funkcji przewodniczącego stowarzyszenia. Działalność członków partii we władzach Klubu również nie była dostateczna. Przejawiało się

17 Tamże, k. 60.

18 Tamże, k. 60.

${ }^{19}$ Funkcję I sekretarza pełnił od 15 lutego 1950 r. Feliks Baranowski. Członkami Egzekutywy KW PZPR byli ponadto: Feliks Berski - przewodniczący WKKP, Stanisław Januszewski - redaktor naczelny "Gazety Poznańskiej”, Józef Kieszczyński - przewodniczący ORZZ, Włodzimierz Migoń - przewodniczący WRN, Wacław Neigart - kierownik Wydziału Kadr KW PZPR, Eugeniusz Patrzałek - kierownik Wydziału Administracyjno-Samorządowego KW PZPR, Stanisław Piotrowicz - I sekretarz KM PZPR w Poznaniu, Henryk Palka - szef WUBP, Bronisław Sokół kierownik Wydziału Organizacyjnego KW PZPR, Tadeusz Sznurkowski - przewodniczący ZW ZMP, i Andrzej Węcławek - I sekretarz KZ PZPR w Zakładach Cegielskiego. Zob. A. Choniawko, Stosunki polityczne w Wielkopolsce 1945-1950, Poznań 1980, s. 200. 
to brakiem zainteresowania posiedzeniami dyskusyjnymi, podczas których wypowiedzi pozostawiały nieraz bardzo dużo do życzenia ${ }^{20}$.

Pod koniec kadencji Błachowskiego jako przewodniczącego, od grudnia 1950 r. do kwietnia 1951 r., nie odbyło się żadne posiedzenie dyskusyjne i zebranie. Należało zatem zintensyfikować działalność towarzystwa.

Okazją do tzw. „nowego otwarcia” było Walne Zebranie 24 kwietnia 1951 r., na którym wybrano nowy Zarząd ${ }^{21}$. Przewodniczącym został dr Zdzisław Kaczmarczyk, prof. Wydziału Prawa Uniwersytetu Poznańskiego - członek Klubu od 1950 r., a sekretarzem Zarządu - Hanna Opuszyńska - z Wydziału Rolniczo-Leśnego UP22.

Nowy Zarząd starał się ożywić działalność Klubu: utworzono grupy dyskusyjne, zorganizowano wspólne zebrania ze Zrzeszeniem Pracowników Instytutu Zachodniego, a jesienią 1951 r. rozpoczęto wydawanie „Biuletynu”, będącego organem informacyjnym stowarzyszenia ${ }^{23}$.

Opracowano także program pracy. Podstawą miały być referaty, które powinny odbywać się raz w miesiącu. Równolegle z referatami planowano stworzyć zespoły dyskusyjne pokrewnych dyscyplin naukowych, np. prawników, przyrodników, filozofów itp. Dostęp do ich prac miał być dostępny dla każdego członka Klubu. Zadaniem tych zespołów miało być pogłębianie znajomości bieżących zagadnień fachowych oraz nawiązanie kontaktów z naukowcami radzieckimi i z państw obozu socjalistycznego.

Ważnym elementem działalności Klubu miały być kursy marksizmu-leninizmu-stalinizmu, prowadzone przez adwokata - dr Juliana Huberta, który w ramach zajęć zleconych wykładał prawo pracy i ubezpieczeń społecznych w Katedrze Prawa Administracyjnego UP. Program kursu miał być identyczny z programem kursów szkolenia ideologicznego drugiego stopnia organizowanych przez Ministerstwo Sprawiedliwości na szczeblu sądów apelacyjnych.

Planowano inicjować współpracę między różnymi działami nauki a życiem praktycznym poprzez organizowanie spotkań naukowców, przodowników pracy i racjonalizatorów oraz włączenie się do prac przygotowawczych Kongresu Nauki Polskiej, planowanego na lato 1951 r. ${ }^{24}$

${ }^{20} \mathrm{~W}$ Ocenie pracy wypomniano POP przy wyższych uczelniach poznańskich, że od początku grudnia 1950 r. do połowy marca 1951 r., a więc w trakcie trwania kadencji prof. Błachowskiego nie wpłynęły na zmianę Zarządu Klubu, k. 60.

${ }^{21}$ APP, KW PZPR w Poznaniu, sygn. 3325, k. 60-61.

22 Zdzisław Kaczmarczyk (1911-1980) - polski prawnik, historyk, niemcoznawca, prof. Uniwersytetu im. Adama Mickiewicza w Poznaniu, dyrektor Instytutu Zachodniego w Poznaniu w latach 1964-1965, prezes Poznańskiego Towarzystwa Przyjaciół Nauk w latach 1975-1980, poseł Sejmu PRL III kadencji. Co ciekawe, członkiem PZPR Kaczmarczyk został dopiero w 1959 r.

${ }^{23}$ APP, KW PZPR w Poznaniu, sygn. 3325, Ocena pracy, k. 61.

${ }^{24}$ W ramach przygotowań do I Kongresu Nauki Polskiej organizator Zespołu Katedr Historii Kultury Materialnej UP prof. Witold Hensel zwrócił się listownie z prośbą do Zarządu 
Uzupełnieniem działalności naukowej i szkolenia ideologicznego miała być także działalność kulturalno-rekreacyjno-wypoczynkowa ${ }^{25}$.

Realizacja pierwszego punktu programu (referaty) napotykała na trudności związane z pozyskaniem prelegentów, którzy z różnych przyczyn nie mogli wystąpić $\mathrm{w}$ planowanym przez Zarząd terminie. $Z$ siedmiu referatów, które miały być odczytane w pierwszym półroczu 1951 r. nie został wygłoszony żaden ${ }^{26}$.

Na jednym z zebrań odbytych wiosną 1951 r. wysunięto wniosek o połączeniu Klubu ze Stowarzyszeniem Asystentów Szkół Akademickich w Poznaniu.

Stowarzyszenie Asystentów Szkół Akademickich w Poznaniu powstało w 1928 r. Działalność swoją wznowiło w lutym 1945 r. Do Stowarzyszenia należeli pomocniczy pracownicy nauki z Uniwersytetu i z ówczesnej Akademii Handlowej. Stowarzyszenie miało siedzibę w gmachach Uniwersytetu; korzystało też z subwencji i innej pomocy ze strony uczelni. $Z$ tego powodu nazywano je nieoficjalnie Stowarzyszeniem Asystentów UP. Stowarzyszenie prowadziło przystań żeglarską w Kiekrzu i dom wypoczynkowy w Karpaczu-Bierutowicach. Do organizacji tej należało ponad dwieście osób. Prezesem Stowarzyszenia w roku akademickim 1950/51 był mgr inż. Jan Czekalski ${ }^{27}$.

W publikowanych źródłach na próżno szukać informacji ${ }^{28}$, kto zadecydował o fuzji obu stowarzyszeń, mających przecież zupełnie inne priorytety swojej działalności. Możemy z dużym prawdopodobieństwem przyjąć, że decyzję tę podjął Komitet Wojewódzki PZPR w Poznaniu.

Klubu o zgodę na odbycie 2 maja 1951 r. konferencji środowiskowej, zorganizowanej z polecenia podsekcji Historii i Prehistorii Kongresu dla przedyskutowania projektu periodyzacji dziejów Polski starożytnej i wczesnośredniowiecznej. Zob. PANAWOP, Materiały Zdzisława Kaczmarczyka (1911-1980), sygn. P.III-68, j.a. 187, k. 2.

${ }^{25}$ APP, KW PZPR w Poznaniu, sygn. 3325, k. 62.

${ }^{26}$ Tamże, Program prac Klubu Demokratycznej Profesury w Poznaniu. Planowane referaty mieli wygłosić: Tadeusz Tomaszewski, Elementy polityczne w nauce ilustrowane przykładami z psychologii; Julian Hubert, Stosowanie metody dialektycznej jako główny środek do podniesienia poziomu badań naukowych; Adam Schaff (temat referatu określić miał sam autor); Marian Muszkat, Zagadnienia kosmopolityzmu w naukach społecznych (a zwłaszcza prawniczych); Seweryn Żurawicki miał przedstawić referat z zakresu nauk ekonomicznych i omówić schyłek pojęć z ekonomiki burżuazyjnej; Kazimierz Ajdukiewicz, Rola i zadania Kongresu Nauki Polskiej; Drewnowski, Podstawy i zasady reorganizacji nauki w Polsce, k. 62. Po kwietniu 1951 r. odbyło się na pewno jedno zebranie dyskusyjne, połączone z referatem Józefa Burszty Społeczeństwo polskie $i$ kwestia alkoholizmu (19 czerwca 1951 r.).; PANAWOP, Materiały Zdzisława Kaczmarczyka (1911-1980), j.a.187, k. 3 .

27 Zob. Kronika Uniwersytetu Poznańskiego za lata akademickie 1945-1954/55, Poznań 1958, s. 818 .

${ }^{28}$ Tamże, s. 819, podano informację, że Stowarzyszenie Asystentów Szkół Akademickich zakończyło swoją działalność w roku 1951. 
Oficjalnie decyzję o połączeniu obu stowarzyszeń podjęto na nadzwyczajnym Walnym Zebraniu Klubu w dniu 30 czerwca 1951 r. ${ }^{29}$ W wyniku fuzji KDP niejako automatyczne pozyskał nowych członków, a poprzez przejęcie zaplecza socjalnego byłego już Stowarzyszenia w Kiekrzu i Karpaczu-Bierutowicach stał się atrakcyjny dla swoich członków z uwagi na możliwości udziału w zorganizowanym wypoczynku.

Działania nowego Zarządu zostały pozytywnie odnotowane w Ocenie, nie wpłynęły jednak na poprawę frekwencji, która była nadal bardzo niska. Np. na posiedzeniu Klubu w maju 1951 r., w związku z dyskusją nad referatem dr. Szweda pt. Nauka przeciw idealizmowi, obecnych było tylko dziewiętnastu na przeszło trzystu członków ${ }^{30}$.

Ważną datą w dziejach nauki polskiej był rok 1951, a to za sprawą I Kongresu Nauki Polskiej, który obradował na przełomie czerwca i lip$\mathrm{ca}^{31}$. Obrady Kongresu i podjęte uchwały miały olbrzymi wpływ na późniejszą działalność oraz ramy organizacyjne nauki polskiej. Również program prac KDP na czwarty kwartał 1951 r. i pierwszy kwartał 1952 r. przewidywał uwzględnienie uchwał Kongresu. W Klubie utworzono sekcje poszczególnych dyscyplin naukowych: a) ekonomiczną - kier. dr Stanisław Waszak; b) biologiczną - kier. prof. Bolesław Kuryłowicz; c) historyczną - kier. prof. Henryk Łowmiański; d) geograficzną - kier. prof. dr Józef Czekalski; e) nauk leśnych - kier. prof. Tadeusz Molenda; f) polonistycznych - kier. Bogdan Zakrzewski; g) chemiczną - kier. Jerzy Suszko; h) nauk prawnych - kier. prof. Antoni Peretiatkowicz ${ }^{32}$.

Jesienią 1951 r. Klub aktywnie włączył się w ogólnopolską działalność „Miesiąca Pogłębiania Przyjaźni Polsko-Radzieckiej”. W „Biuletynie” Klubu z października tego roku Zarząd zwrócił się „,z gorącym apelem do wszystkich

29 PANAWOP, Materiały Zdzisława Kaczmarczyka (1911-1980), sygn. P.III-68, j.a. 187. Pismo Zarządu Klubu z dnia 16 czerwca 1951 r. zawiadamiające o terminie Nadzwyczajnego Walnego Zebrania członków w sprawie połączenia Klubu Demokratycznej Profesury i Stowarzyszenia Asystentów Szkół Akademickich w Poznaniu, k. 4. Było to bardziej wchłonięcie niż fuzja. Przy okazji Klub przejął cały majątek Stowarzyszenia: przystań żeglarską na Jeziorze Kierskim w Poznaniu z całym zapleczem oraz dom wypoczynkowy "Niewódka” w KarpaczuBierutowicach, k. 4.

30 APP, KW PZPR w Poznaniu, sygn. 3325, Ocenia pracy, k. 61.

${ }^{31}$ I Kongres Nauki Polskiej obradował w Warszawie od 29 czerwca do 2 lipca 1951 r. Postanowienia Kongresu legły u podstaw powołania Polskiej Akademii Nauk. Kongres skupił blisko dwa tys. uczonych, w tym z Polskiej Akademii Umiejętności i z Towarzystwa Naukowego Warszawskiego, które przyjęło nowy trójczłonowy model organizacji nauki w Polsce, mający stworzyć szansę na poważne, stabilne finansowanie oraz szybszy postęp badań, prowadzonych i rozwijanych w nowoczesnym centrum badawczym. W myśl postulowanego modelu, Akademia miała prowadzić badania, szkoły wyższe - kształcić adeptów wiedzy, a towarzystwa naukowe - wiedzę tę upowszechniać.

32 PANAWOP, Materiały Zdzisława Kaczmarczyka (1911-1980), j.a. 187, Program prac Klubu Demokratycznej Profesury na IV kw. 1951 i I kw. 1952, k. 10. 
Kolegów, aby w Miesiącu Pogłębiania Przyjaźni Polsko-Radzieckiej (15 października - 5 listopada) poświęcili jeden wykład względnie ćwiczenia na zapoznanie studentów z najnowszymi zdobyczami nauki radzieckiej, jej politycznemu i praktycznemu znaczeniu" ${ }^{\prime 3}$. 2 listopada dr Bolesław Hornowski wygłosił w siedzibie towarzystwa referat pt. Antoni Makarenko-czołowy pedagog radziecki.

Działalność Klubu przerwał na początku listopada pożar, który wybuchł na skutek nieostrożności jednego z pracowników technicznych. Na szczęście ogień szybko ugaszono i straty były niewielkie. Po remoncie lokalu Klub wznowił działalność 24 listopada, o czym poinformował członków w 3 numerze „Biuletynu”. Lokal był czynny codziennie oprócz niedziel i świat w od 12.00 do 20.00. W świeżo odremontowanej sali czynne były czytelnia czasopism krajowych i zagranicznych oraz bufet. Zarząd zapraszał „Kolegów do korzystania z lokalu Klubu i wraża nadzieje, że stanie się on miejscem spotkań koleżeńskich, oraz ośrodkiem wymiany myśli i wypoczynku dla ogółu członków"34.

Nie zaniedbywano działalności odczytowej: 27 listopada dr Szczęsny Gnatowski z ramienia Zrzeszenia Przyrodników Marksistów wygłosił referat pt. Rozwój pogladów na budowę materii; 7 grudnia prof. dr Bolesław Kuryłowicz przedstawił (pierwsze z cyklu wystąpień planowanych przez Zarząd Klubu na sezon 1951/52) referat pt. Czy nauki przyrodnicze należa do nadbudowy; 14 grudnia dr Władysław Kufel wygłosił referat Nowelizacja Kodeksu Postępowania Cywilnego na tle ostatniego Zjazdu Procesualistów, a 4 stycznia 1952 r. powtórnie wystąpił prof. Kuryłowicz z referatem Rola przemiany materii w organizmach roślinnych $w$ świetle nauki radzieckiej ${ }^{35}$.

Pierwszy kwartał 1952 r. działalność odczytową Klubu zdominowała dyskusja nad projektem nowej Konstytucji. Cykl odczytów poświęconych nowej ustawie zasadniczej zainaugurował 8 lutego dr Wiktor Jaśkiewicz referatem pt. O projekcie nowej Konstytucji Polskiej Rzeczypospolitej Ludowej. 29 lutego w lokalu Klubu wystąpił prof. Antoni Peretiatkowicz z referatem pt. Organizacja władz najwyższych w projekcie Nowej Konstytucji. 18 marca odczyt miał prof. Alfred Ohanowicz (Wtasność w projekcie Nowej Konstytucji), 25 marca - Marian Zimmerman (Rady Narodowe w projekcie Nowej Konstytucji), 8 kwietnia Marian Jedlicki (Prawa obywatelskie w państwie burżuazyjnym i socjalistycznym), a 22 kwietnia - Władysław Siedlecki (Wymiar sprawiedliwości w projekcie Nowej

33 Tamże, „Biuletyn” nr 1/51 z 10 października 1951 r., k. 7.

34 Tamże, "Biuletyn” nr 3/51 z 20 listopada 1951 r., k. 14.

35 Tamże, „Biuletyn” nr 5/51 z 17 grudnia 1951 r., k. 16. Zaangażowanie prof. Kuryłowicza nie było przypadkowe. W 1949 r. był on członkiem PZPR na Uniwersytecie Poznańskim. 
Konstytucji); oraz dr Karol M. Pospieszalski - Praca i człowiek pracy w projekcie Nowej Konstytucji $i^{36}$.

Po każdym odczycie miała miejsce dyskusja; oczywiście, jakakolwiek krytyka projektu Konstytucji przez uczestnika dyskusji mogła mieć dla niego przykre następstwa. W realiach okresu szczy towego stalinizmu wszyscy zdawali sobie $\mathrm{z}$ tego doskonale sprawę $e^{37}$.

W ramach obowiązującego wówczas „kultu jednostki” nie mogło zabraknąć referatów poświęconych Bolesławowi Bierutowi. Doskonałą do tego okazją był jubileusz 60-lecia urodzin Sekretarza Generalnego PZPR i Prezydenta Rzeczypospolitej Polskiej, hucznie świętowany w całym kraju. Z tej okazji 13 maja 1952 r. Klub przygotował cykl referatów pod znamiennym tytułem Bolesław Bierut jako teoretyk marksizmu, na które złożyły się następujące tematy (w kolejności wystąpień): mgr Władysław Markiewicz, Zagadnienie sojuszu robotniczo-chtopskiego; dr Jerzy Kossak, Zagadnienie państwa i dyktatury proletariatu; dr Józef Kwiatek, Zagadnienie wychowania socjalistycznego. W majowym „Biuletynie” Zarząd prosił „Kolegów o wzięcie jak najliczniejszego udziału w powyższym zebraniu referatowym, które będzie nie tylko wyrazem naszych uczuć dla Prezydenta Bieruta, ale zarazem przyczyni się do rozszerzenia naszej wiedzy marksistowskiej" 38 .

Rola KDP nie ograniczała się tylko do miejsca spotkań środowiska, akademickiego Poznania, organizowania odczytów naukowych czy dyskusji. Klub abonował szereg czasopism polskich i zagranicznych, a ponad to jego członkowie mogli korzystać z kilkudziesięciu czasopism naukowych (przeważnie radzieckich), które - będąc własnością Zrzeszenia Przyrodników Marksistów były stale do dyspozycji w lokalu Klubu. Ważne miejsce zajmowała szeroko pojęta działalność kulturalno-rekreacyjno-wypoczynkowa. Przejawiało się to m.in. poprzez organizowanie: kursów języka rosyjskiego, wystawy obrazów członków Klubu, zabaw tanecznych i sylwestrowych, tzw. choinki noworocznej, turnusów wczasowych w domu wypoczynkowym „Niewódka".

36 Tamże, „Biuletyn” nr 2/52 z 3 lutego 1952 r., k. 20; „Biuletyn” nr 3/52 z 22 lutego 1952 r., k. 22; „Biuletyn” nr 4/9/52 z 12 marca 1952 r., k. 25; „Biuletyn” nr 5/10/52 z 31 marca 1952 r., k. 27.

${ }^{37}$ Konstytucja uchwalona przez Sejm Ustawodawczy 22 lipca 1952 r., opublikowana 23 lipca 1952 r., weszła w życie 23 lipca 1952 r. z mocą obowiązującą od 22 lipca 1952 r.; zmieniona 1 stycznia 1990 r. w Konstytucję Rzeczypospolitej Polskiej. W pierwotnej postaci opracowana została wg wzoru stalinowskiej konstytucji ZSRR z 1936 r. Była ona głównie aktem deklaratywno-propagandowym. Nie regulowała działania głównego ośrodka władzy politycznej, czyli PZPR, skąd wynikała jej fasadowość. W praktyce Konstytucja miała mniejsze znaczenie niż statut PZPR, który wprost odwoływał się do idei komunistycznej.

38 PANAWOP, Materiały Zdzisława Kaczmarczyka (1911-1980), j.a. 187, „Biuletyn” nr 5/10/52 r. z dnia 3 lutego 1952 r., k. 31. 
Organizacją spotkań towarzyskich i wypoczynkiem w ramach Klubu zajmowały się sekcje towarzyska i wypoczynkowa ${ }^{39}$.

W marcu 1953 r. zmarł Józef Stalin. Jego śmierć, przez niektórych historyków uważna za początek „odwilży” w krajach obozu socjalistycznego, była powodem incydentu, do jakiego doszło w siedzibie Klubu z udziałem ks. prof. Szczęsnego Dettloffa ${ }^{40}$, który poniósł z tego powodu poważne konsekwencje, a cała sprawa odbiła się głośnym echem w środowisku akademickim Poznania.

Incydent ten przedstawił obszernie Piotr Grzelczak w artykule Sprawa ks. Szczęsnego Dettloffa ${ }^{41}$. Nas interesuje wątek zapoczątkowany w lokalu Klubu. „Pechowym dniem dla ks. prof. Szczęsnego Dettloffa okazał się 6 marca 1953 r. Tego dnia »Gazeta Poznańska«, która ukazała się później niż zwykle i wyszła w żałobnej szacie, na pierwszej stronie informowała: »Przestało bić serce wodza ludzkości - Wielkiego Stalina «. [...] Tego feralnego dnia, ks. prof. Szczęsny Dettloff umówił się na spotkanie z prof. Zdzisławem Kępińskim, miało się ono odbyć w godzinach popołudniowych w lokalu Klubu Demokratycznej Profesury w Poznaniu przy Placu Wolności 5. Oczekując na przybycie swojego współpracownika, ks. prof. Dettloff odbył krótką, niezobowiązującą rozmowę $\mathrm{z}$ dwiema pracownicami zatrudnionymi $\mathrm{w}$ tym lokalu na stanowiskach: bufetowej ${ }^{42}$ oraz sekretarki technicznej ${ }^{43}$. Zgodnie z wyjaśnieniami, których kilka dni później był zmuszony udzielić na polecenie rektora UP prof. Jerzego Suszki, przywitał się z personelem słowami: »Złóżmy sobie kondolencje«, a następnie w toku rozmowy przy stoliku zauważył: »żaden materializm ani inne nastawienie ideologiczne nie uratują człowieka od śmierci«. W następnych dniach te, dziś wydawać by się mogło, niewinne słowa, oczywiście nie bez udziału władz partyjnych, wywołały w poznańskim środowisku akademickim prawdziwą »burzę«" 44 .

Rozpoczęła się brutalna nagonka na ks. profesora, w której czołową rolę odgrywały Komitet Wojewódzki PZPR w Poznaniu oraz Oddziałowa Organizacja Partyjna przy Uniwersytecie Poznańskim. W celu wyjaśnienia spra-

${ }^{39}$ PANAWOP, Materiały Stefana Błachowskiego, Sprawozdanie Przewodniczącego, k. 9; tamże, Materiały Zdzisława Kaczmarczyka, „Biuletyn” nr 2 z 29 października 1951 r., k. 9; Program prac Klubu Demokratycznej Profesury na IV kw. 51 i I kw. 52, k. 10; „Biuletyn” nr 3 z 20 listopada 1951 r., k. 14; „Biuletyn” nr 4/51 z 5 grudnia 1951 r.; „Biuletyn” nr 5/51 z 17 grudnia 1951 r., k. 16; „Biuletyn” nr 2/7/52 z 17 grudnia 1951 r., k. 20.

${ }^{40}$ Ks. Szczęsny Dettloff (1878-1961) - historyk sztuki, duchowny katolicki, prof. Uniwersytetu im. Adama Mickiewicza, kierownik Katedry Historii Sztuki, członek Poznańskiego Towarzystwa Przyjaciół Nauk, członek rzeczywisty Polskiej Akademii Nauk.

41 Zob. P. Grzelczak, Sprawa ks. Szczęsnego Dettloffa, "Artium Quaestiones”, 2011, t. 22, s. 79-100 .

42 Józefa Grabska.

${ }^{43}$ Maria Prędka.

44 Przestało bić serce wodza ludzkości - Wielkiego Stalina, "Gazeta Poznańska” 1953, nr 55. 
wy Senat UP powołał 8 marca Komisję Senacką ${ }^{45}$, która z zapałem rozpoczęła swoją działalność (m.in. poprzez dokonanie konfrontacji pomiędzy ks. Dettloffem a sekretarką techniczną i bufetową) i szybko orzekła jednoznacznie o „winie” ks. profesora. Swój wniosek w formie projektu uchwały Komisja przekazała następnie na posiedzenie Senatu UP 12 marca, kiedy postanowiono wdrożyć postępowanie dyscyplinarne wobec ks. profesora i zawiesić go w obowiązkach wykładowcy. Kolejne dni na uczelni upłynęły $\mathrm{w}$ atmosferze nagonki, podsycanej przez uczelniane struktury PZPR i ZMP. 20 marca odbyło się nadzwyczajne posiedzenie Senatu UP, na którym jednogłośnie uchwalono zwrócić się do ministra szkolnictwa wyższego o natychmiastowe rozwiązanie stosunku służbowego z ks. prof. Dettloffem. Wniosek został przyjęty i od 20 marca 1953 r. ks. Szczęsny Dettloff znalazł się na przymusowej emeryturze ${ }^{46}$.

Sprawa ks. Detloffa miała także pewne konsekwencje dla poznańskiego Klubu. Dotychczasowy przewodniczący Zarządu prof. Zdzisław Kaczmarczyk, który stanął przed dylematem, czy poprzeć wniosek o zwolnienie z pracy na Uniwersytecie ks. profesora, postanowił wystąpić z Klubu ${ }^{47}$.

Od połowy 1952 r. działalność stowarzyszenia zaczęła powoli zamierać. Być może miało to związek z planami przekształcenia KDP w Sekcję Szkół Wyższych Związku Nauczycielstwa Polskiego. Projekt ten przedstawiono na zebraniu członków towarzystwa 20 maja 1952 r. ${ }^{48}$

Środowisko akademickie Poznania szybko zorientowało się, że w Klubie trudno o rzeczową, konstruktywną dyskusję bez obawy, że wypowiedziane słowo może mieć przykre następstwa, o czym osobiście przekonał się ks. prof. Dettloff (w zasadzie było to niemożliwe od samego początku funkcjonowania stowarzyszenia). Również nowi członkowie szybko uświadomili sobie, że Klub Demokratycznej Profesury nie był czymś na kształt np. Poznańskiego Towarzystwa Przyjaciół Nauk, ale stowarzyszeniem o jasno sprecyzowanym kierunku działania politycznego.

Podobnie rzecz się miała z wygłaszanymi referatami. Raziła w nich nachalna propaganda nowego ustroju, kult jednostki i bezkrytyczna gloryfika-

${ }^{45} \mathrm{~W}$ jej skład weszli: rektor UP prof. Jerzy Suszko, prorektorzy prof. Szczepan Sczeniowski i zastępca profesora dr Wiktor Jaśkiewicz, dziekan Wydziału Filozoficzno-Historycznego prof. Witold Hensel, zastępca rektora ds. administracyjnych mgr Tadeusz Klanowski, I sekretarz KU PZPR przy UP Zdzisław Wroniak oraz członek tej partyjnej instancji dr Józef Kwiatek.

${ }^{46}$ Sprawa ks. Szczęsnego, s. 4-11. We wrześniu 1956 r. specjalna Komisja Rektorska powołana przez rektora Jerzego Suszkę przeanalizowała jeszcze raz materiały dotyczące okoliczności zwolnienia ks. profesora i zaproponowała anulowanie poprzednich, krzywdzących uchwał oraz przywrócenie go do pracy na stanowisko samodzielnego pracownika naukowego UAM. Wniosek został pozytywnie rozpatrzony przez Senat

${ }^{47}$ H. Olszewski, Zdzisław Kaczmarczyk 1911-1980, Poznań 2005, s. 94-95. Autorowi nie udało się ustalić, kto został jego następcą.

48 Tamże, k. 33. 
cja osiągnięć naukowych, gospodarczych i kulturalnych ZSRR. Dlatego też, mimo dużej liczby członków ${ }^{49}$, frekwencja na spotkaniach dyskusyjnych i odczytach była niska, na co skarżyli się towarzysze z Komitetu Wojewódzkiego w Poznaniu. Szybko stało się jasne, że koncepcja przekonania poznańskich naukowców do nowego ustroju spełzła na niczym (choć zdarzały się osoby, które bez zastrzeżeń zaakceptowały powojenną rzeczywistość).

Autor zdaje sobie sprawę, że artykuł nie wyczerpał całości zagadnienia roli i znaczenia poznańskiego Klubu Demokratycznej Profesury w szerokiej akcji nakłaniania przez ówczesne władze przedstawicieli środowiska akademickiego Poznania, do pozytywnej akceptacji zmian politycznych i społecznych jakie zaszły w Polsce po II wojnie światowej. Działalność Klubu w Poznaniu, jak i na terenie całego kraju, nie jest jeszcze szczegółowo zbadana. Niech ten artykuł będzie swoistym zaczynem do podjęcia w tej kwestii dalszych szerokich badań.

Jarosław Matysiak

\section{Klub Demokratycznej Profesury w Poznaniu w latach (1949) - 1950-1953}

\section{Streszczenie}

Artykuł przedstawia organizację i działalność Klubu Demokratycznej Profesury w Poznaniu w latach 1950-1953. Funkcjonowanie Klubu było częścią planu władz komunistycznych, które po zdobyciu władzy w Polsce po II wojnie światowej dążyły do podporządkowania sobie szkół wyższych i kadry naukowej, nie tylko poprzez zarządzenia administracyjne, ale także poprzez działalność różnego rodzaju towarzystw, organizacji i stowarzyszeń, które miały za zadanie gromadzić wykładowców oraz badaczy i kształtować ich w duchu socjalistycznym. Za pomocą tych towarzystw i organizacji planowano uzyskać w środowisku akademickim przychylność i poparcie dla zmian, które zachodziły w kraju.

Autor omówił kulisy powstania Klubu Demokratycznej Profesury w Poznaniu, ukonstytuowanie się Zarządu oraz różne formy działalności stowarzyszenia: wykłady, odczyty, pogadanki, prelekcje, zebrania i posiedzenia dyskusyjne (przeważnie dotyczące dorobku naukowego ZSRR i metodologii marksistowsko-leninowskiej) oraz działalność socjalną na rzecz członków Klubu w okresie, kiedy przewodniczącymi byli profesorowie Uniwersytetu Poznańskiego Stefan Błachowski i Zdzisław Kaczmarczyk.

49 Trudno dzisiaj jednoznacznie rozstrzygnąć, jakie motywy kierowały wstępującymi do Klubu: możliwość intelektualnej dyskusji, czysty koniunkturalizm i szansa na skorzystanie z przynależnych członkom Klubu beneficjentów czy też chęć przypodobania się ówczesnym władzom. 


\title{
The Democratic Professors' Club in Poznań in the years (1949) - 1950-1953
}

\begin{abstract}
The article presents the organization and the activity of the Democratic Professors' Club in Poznań in the years 1950-1953. The functioning of the Club was a part of the communist authorities' plan. After their rise to power in Poland after the Second World War, they aimed at subordinating universities and academic staff not only through administrative decisions, but also through the activity of various clubs, organizations and associations, which were supposed to gather lecturers and academics and educate them in the socialist spirit. Those clubs and associations were supposed to encourage the academic environment to support changes which were being introduced in the country.

The author discusses the creation of the Democratic Professors' Club in Poznan, the establishment of its Board, as well as various forms of the society's activity: lectures, talks, seminars, workshops, meetings and discussions (usually concerning the academic achievements of the USSR, and Marxist and Leninist methodology) and the social activity of Club members in the period when it was headed by Stefan Błachowski and Zdzisław Kaczmarczyk, professors at Poznań University.
\end{abstract}

